\title{
Application of Ayurvedic Principles in Prevention and Management of Behavioural Problems in Children
}

\author{
Review Article
}

\section{Renu Rathi ${ }^{*}$, Bharat Rathi²}

1. Professor, Department of Kaumarabhritya, 2. Professor, Department of Rasashastra Bhaishjya Kalpana,

Mahatma Gandhi Ayurveda College Hospital \& Research Centre, Salod (H) Wardha, (MS),

Datta Meghe Institute of Medical Sciences (Deemed to be University), Sawangi (Meghe) Wardha. India.

\begin{abstract}
Introduction: Behavioral problems are commonly prevalent worldwide. It is important to diagnose and treat timely as if untreated, increase the risk of getting psychiatric illnesses. Present review is aimed at providing Ayurvedic guidelines in the form of Sadvritta (Code of conduct), Achar rasayan-AR (ethical principles) and few Ayurveda interventions correlating with recently developed interventions of Psychology which may prove helpful in prevention and management of behavioral problems in children. Material and Methods: This review is based on data collected from classical Ayurvedic literature, published research works in various journals and counselling experiences. Observations and Results: Behavioral problems are generally multi-factorial in origin and arise as a result of conflict between the children's personality, attitudes of parents, teacher or peers. Counselling with family and adoption of Ayurveda principles can manage and prevent further progress of behavioral problems in children. Satvavjay Chikitsa-SC (non-drug psychotherapy), Achar Rasayana and Sadvritta, Yog are Ayurvedic ways to balance Satva (good qualities of mind), (Passionate, agitated), Tama (Laziness, lack of concentration) applicable in prevention of behavioral problems. Conclusion: Ayurvedic principles such as AR, Sadvritta and SC are best nonpharmacological modalities required for early detection and prevention of behavioral problems. Knowledge, education and proper expressions of code, conduct or etiquettes along with Ayurveda interventions such as use of Medhya (nervine tonic/nootropic) drugs, Panchkarma pre-procedures can prove to be a significant therapeutic way to combat behavioral disorders.
\end{abstract}

Key Words: Achar Rasayan, Ayurveda interventions, Behavioral problems in children, Sadvritta, Satvavjay Chikitsa.

\section{Introduction}

According to World Health Organization, mental health disorders are one of the leading causes of disability worldwide (1). Behavioral problems of children are becoming common and roughly 6 million children globally (2) and out of these $33.4 \%$ in India are affected by different behavioral problems (3). Poor parenting is one of the leading causes for occurrence of behavioral problems (4). It is noted that ferociousness, impulsivity in children has increased significantly as compare to couple of decades ago. Research studies have proven that strong child-parent relationship, friendly family environment, good faith and understanding among family members, peers and teachers are key factors in development of children's personality (5). Behavioral disorder is a mental ailment diagnosed in childhood age that presents a repetitive and persistent pattern that violates the basic rights or

\section{* Corresponding Author:}

\section{Renu Rathi}

Professor, Department of Kaumarabhritya, Mahatma Gandhi Ayurveda College Hospital \& Research Centre, Salod (H) Wardha, (MS), Datta Meghe Institute of Medical Sciences (Deemed to be University) Sawangi (Meghe) Wardha, India.

Email Id: rbr.226@gmail.com norms. They include aggressive, destructive odd behaviour, lying, vandalism, anxiety etc. (6). In Charaka Samhita it has been categorically mentioned that all diseases cannot be named but need to understand its basic concepts and accordingly can be treated (7) There are few guidelines in Ayurveda which can prove beneficial in prevention and management of behavioral problems. Some interventions have been advised such as Sadvritta, Achar Rasayan AR (good conduct) and Satvavajaya Chikitsa SC (mind control therapy) which can be applied in prevention of psychological disorders including behavioral problems (8). Sadvritta and AR are simple tips regarding how to behave with others and considered as alternative to get rejuvenation effects; described in Ayurvedic classics (9) $\mathrm{SC}$ is psychic therapy for withdrawal of mind from harmful objects and thoughts. (10) It is the need of hour to explore the role of Ayurveda in present circumstances.

Before conception itself, Ayurveda has been given emphasis towards balancing Doshas (three fundamental factors of body i.e. Vata, Pitta and Kapha) of parents through Shodhan (body purificatory measures) and Rasayan (immune-modulatory measures) to ensure the healthy progeny. (11) Thereby, physical and mental health of parents and in turn newborn's is also maintained. Improper care during pregnancy and delivery may seriously affect the physical as well as mental development of the child. Even if mother is in 
stress during pregnancy, results in poor mental development of fetus which later develops into behavioral problems in children (12)

Nutrition plays an important role to maintain good growth and development during gestation and later in lactation period which also improve the quality of breast feeding, essential tool required for both physical and mental development of child. $(13,14)$

Childhood age is the appropriate time of personality building, development of manners, etiquettes and reposes good habits. However, children are unaware of any of these hence, it is the duty of parents to take utmost care during this period. Family members, peers, teachers as well as genetic, dietary and environmental factors are responsible for development of child's personality (15). They must utilize their potential to boost confidence, practical wisdom and inculcate good qualities in children by proper education and maintaining personality nourishing environment. To achieve these traits some guidelines are must. In present work, an attempt has been made to present a review of Ayurveda principles related to prevention and management for various behavioral problems.

\section{Material and Methods}

This review is structured on data congregated from Ayurvedic compendia, text books of psychology; journals and researches related to depression, child behaviour \& development. The study also includes Ayurveda concepts related to Psychotherapy, SC and personal counselling experiences of last 20 years. A meticulous understanding, co-relation with analysis has been carried out to highlight this issue.

\section{Observations and Results}

\section{Origin of psychosomatic disorder (PD) \& behavioral disorders (BD)}

According to Ayurveda, the fetal expressions are transformed to mother through sensory-motor path ways and expressed in the form of various desires of mothers (Dauhridavastha); if their needs are not fulfilled or use of Garbhopghatkar bhavas (harmful measures to fetus) then it may be a cause of these disorders. It can be interpreted that the desires of mothers towards various diet is for fulfilling the need of proteins, vitamins and mineral supplements to facilitates efficient organogenesis and mental development too. Thus, if mother's desires are ignored during Dauhridavastha then it may result in deficiency of vital requirements of fetus; and such deficiencies cause malformation of nervous system in the born child and may have various psychological problems. (16)

Lack of proper awareness from parents or lack of encouraging re-enforcement in kids to accomplish task, results in distress, loss of self-confidence and lowdown self-respect which may leads into depression $(17,18)$. Traumatic incidents like sudden demise of near and dear, poor mental health due to nervousness, stress and strain, need of societal and emotional support, poor parenting and prenatal stress cause to develop learning, behavioral and developmental disorders, these are few key reasons for the origin of PD and BD (19).
Excluding prenatal and traumatic reasons, recurrent disappointment is common reason in all other causative factors. Brain is the main site of Mana when gets vitiated with Tridosha and Raja-tama obstruct the manovah strotas and creates different behavioral problems in children (20) .

\section{Role of Satvavajay Chikitsa (C)}

SC may include Ayurvedic psychotherapy, counseling, play therapy, cognitive behavioral therapyCBT, meditation, mind control, problem solving approach, assurance and measures to boost Satva and minimize Raja-tama of mind. (21) In Satvavajaya concept, it is clearly mentioned that for wellness of mind all sensual factors such as diet, words, visual objects, material objects etc should be within limit of tolerance. Unwholesome diet has very important role in maintenance of Satva dominance of mind in turn helps to preserve health (22).

\section{Role of Achar Rasayan and Sadvritta}

It refers to those acts of parents which ensure safe, firm discipline with pragmatic expectations, create affirmative learning environment, provide interactive caring and unconditional love. $(23,24)$ Parenting is a skill which even some of the biological parents have failed to cultivate. Buckling under the pulls and pressures of the fast-paced modern life, most of the parents often unintentionally commit the crime of neglecting to cater various needs of their children (25). Fulfilling only the material needs of a child and giving $\mathrm{him} / \mathrm{her}$ a comfortable and luxurious life is just one part of the best child care program. On the other hand, the pre requisite component of emotional care and close bonding looks conspicuously missing in many cases. Spending time with little one and engaging in conversations with child is more important than buying digital toys. Parenting is an art, so parents must master it with care which is essential for better growth and development of their younger children. Few attributes of good parents include, a good role model who knows how to explore talent and skills to become problem solver and responsible too. (26)

Ayurveda advocates Sanskaras or etiquettes adoption to balance Raja and Tama and boost Satva to remain away from mental ailments. There are so many behavioral problems occurs in childhood age if code of conduct is not adopted properly. According to Ayurveda all ailments develop due to three basic reasonsAsatmyendriyartha Samyoga (incompatible contact of sense organs), Pragyaparadha (intellectual blasphemy), Parinama (time factor for chronological error). It is the inducer of all pathological conditions of body and mind, vitiates all Sharirik and ManasDoshas(CharakSharir) (27). Table no $\mathbf{1}$ is showing details of Behavioral disorders and its management and complications if left untreated or not treated soon. $(6,21,28)$ There were few research works done in this regard. Table no 2 is showing current status of research work done regarding BD and PD with outcome of research by Ayurveda interventions. BD and PD kind of problems are complex in origin so require multimodal treatment strategy. 
Table no. 1: Showing details of behavioral problems and its management

\begin{tabular}{|c|c|c|c|c|c|c|}
\hline $\begin{array}{l}\text { S. } \\
\text { NN }\end{array}$ & $\begin{array}{l}\text { Behavioral } \\
\text { Problems }\end{array}$ & $\begin{array}{l}\text { Clinical } \\
\text { Features }\end{array}$ & Causes & $\begin{array}{l}\text { Compli- } \\
\text { Cations }\end{array}$ & $\begin{array}{l}\text { External } \\
\text { Treatment }\end{array}$ & $\begin{array}{l}\text { Internal } \\
\text { Treatment }\end{array}$ \\
\hline 1 & ADHD, Autism & $\begin{array}{l}\text { Hyperactive, } \\
\text { poor attention, } \\
\text { slow in } \\
\text { academics, } \\
\text { defiant inter- } \\
\text { personal } \\
\text { relationship }\end{array}$ & $\begin{array}{l}\text { Stress, pre-natal, } \\
\text { natal, post-natal } \\
\text { origin, less quality } \\
\text { time sharing by } \\
\text { parents with wards. }\end{array}$ & $\begin{array}{l}\text { Loss of } \\
\text { confidence, } \\
\text { frustration, } \\
\text { inferiority, } \\
\text { depression, } \\
\text { low self } \\
\text { esteem }\end{array}$ & $\begin{array}{l}\text { Shiro- } \\
\text { Dhara, } \\
\text { Abhang, } \\
\text { Shirolepa, } \\
\text { shiropichu, } \\
\text { Snehan- } \\
\text { Swedan, } \\
\text { Matrabasti }\end{array}$ & $\begin{array}{l}\text { Medhya, Balya, } \\
\text { Vatahar, } \\
\text { BruhanRasayan, } \\
\text { Snehapan, } \\
\text { counseling of } \\
\text { parents, play, } \\
\text { cognitive } \\
\text { therapy to child }\end{array}$ \\
\hline 2 & $\begin{array}{l}\text { ODD- } \\
\text { Oppositional } \\
\text { defiant disorder }\end{array}$ & $\begin{array}{l}\text { Negativistic } \\
\text { attitude, dis- } \\
\text { obedient, } \\
\text { hostile } \\
\text { behavior, } \\
\text { Frequent } \\
\text { arguments, } \\
\text { annoyance, no } \\
\text { physical } \\
\text { aggression }\end{array}$ & $\begin{array}{l}\text { Bad parent-child } \\
\text { relationship, no } \\
\text { good parenting, } \\
\text { insecurity, lack of } \\
\text { love \& care, bad } \\
\text { peer group, busy, } \\
\text { over-burdened } \\
\text { parents, unfulfilled } \\
\text { dreams of parents } \\
\text { for child }\end{array}$ & $\begin{array}{l}\text { Schizophrenia, } \\
\text { addiction to } \\
\text { drugs, may } \\
\text { become } \\
\text { criminal }\end{array}$ & $\begin{array}{l}\text { Above all } \\
\text { Rule out \& } \\
\text { avoid } \\
\text { cause/s }\end{array}$ & $\begin{array}{l}\text { Psychologists } \\
\text { positive } \\
\text { enforcement } \\
\text { Counseling, }\end{array}$ \\
\hline 3 & $\begin{array}{l}\text { Conduct } \\
\text { disorder }\end{array}$ & $\begin{array}{l}\text { Just above all } \\
\text { features with } \\
\text { intense } \\
\text { violation, } \\
\text { aggression, } \\
\text { physical harm } \\
\text { to self \& others }\end{array}$ & $\begin{array}{l}\text { Lack of love \& care } \\
\text { by parents, } \\
\text { Above all causes }\end{array}$ & $\begin{array}{l}\text { Psychiatric } \\
\text { disorders, } \\
\text { Above all }\end{array}$ & $\begin{array}{l}\text { Above all } \\
\text { pre } \\
\text { procedures }\end{array}$ & Above all \\
\hline 4 & $\begin{array}{l}\text { Psychosomatic } \\
\text { disorders like } \\
\text { enuresis, pica, } \\
\text { breath holding } \\
\text { spell, thumb } \\
\text { sucking, etc. }\end{array}$ & $\begin{array}{l}\text { Different as per } \\
\text { problem } \\
\text { mentioned } \\
\text { Impulsiveness, } \\
\text { jitteriness }\end{array}$ & $\begin{array}{l}\text { Lack of love \& care } \\
\text { by parents. } \\
\text { Above all causes }\end{array}$ & $\begin{array}{l}\text { Resolves } \\
\text { automatically }\end{array}$ & $\begin{array}{l}\text { above all } \\
\text { pre } \\
\text { procedure }\end{array}$ & Above all \\
\hline
\end{tabular}

Table no 2, showing Research work done on behavioral problems of children

\begin{tabular}{|c|c|c|c|}
\hline No & Behavioral Problems & Research done & Outcome \\
\hline 1 & *ADHD $(28,29)$ & $\begin{array}{l}\text { Medhya (memory booster) medicines }+ \\
\text { Panchakarma pre-procedures }\end{array}$ & $\begin{array}{l}\text { Better results than only } \\
\text { conventional one. }\end{array}$ \\
\hline 2 & Autism (20) & ${ }^{*} \mathrm{CAM}+$ Yogasanas $\&$ meditation & $\begin{array}{l}\text { Multimodal therapy proved } \\
\text { more beneficial. }\end{array}$ \\
\hline 3 & $\begin{array}{l}\text { Conduct disorders } \\
(30)\end{array}$ & Satvavajay, AcharRasayan, Sadvritta & $\begin{array}{l}\text { Improves the condition with } \\
\text { other measures. }\end{array}$ \\
\hline 4 & $\begin{array}{l}\text { Psychosomatic \& habit } \\
\text { disorders (31) }\end{array}$ & $\begin{array}{l}\text { Achar Rasayana, Satvavajay - corrections in } \\
\text { family environmental causes }\end{array}$ & Symptoms slightly relieved. \\
\hline 5 & $\begin{array}{l}\text { Learning disabilities, } \\
\text { developmental delay } \\
\text { (32) }\end{array}$ & Ayurveda drugs, panchkarma & Mental health promoting effect \\
\hline
\end{tabular}

*ADHD=Attention Deficit Hyperactive Disorder, HIE=hypoxic ischemic encephalopathy, NBID= Neurodevelopmental behavioral intellectual disorders, $\mathrm{CAM}=$ complementary $\&$ alternative medicine

There is important role of Panchkarma if Doshas are more vitiated to eliminate ama/toxins with ease and prepanchkarma procedures are helpful to pacify comparatively less vitiated fundamental factors respectively. Any disorder occurs when there is physical or mental Doshic imbalance. There are five purificatory/Shodhan measuresVaman (medicated induced emesis), Virechan (scientific induced purgation), Nasya (medicine instillation in nostrils), Basti (medicated oil/decoction instillation inside rectum) and Raktamokshan (bloodletting). Some important preprocedures are Shirolep/Talapodichhil (medicated external application on scalp), Shirodhara (pouring of a stream of medicated liquid on head) snehan (oleation therapy), Swedan (hot fomentation) etc. are meant for rehabilitate and facilitate the major five procedures. $(20,33)$ Table no. 3 is depicting different Panchakarma pre-procedures with their mode of action helping to cure as well as prevent behavioral problems in children. 
Renu Rathi et.al., Ayurveda approach to Behavioral problems

Table no. 3 depicting different Panchakarma pre-procedural mode of action proven by research

No. Procedure

\section{Mode of Action}

$1 \quad$ Shirodhara

2 Talapothichhil / shirolepa

$3 \quad$ Nasya-medicated oil instillation

4 Snehan-swedan
Vasodilatation, tranquilizing effect due to increase in brain circulation, Cognition, improved memory, sleep, Relieves irritability $(12,20)$

Calm and cooling effect, mood regulation. $(8,33)$

Stimulant action on brain and its sensory-motor centers. Relieved symptoms of ADHD, Autism, stimulant efficacy to brain $(12,28)$

Nourishment to skin, muscles, nerve endings, vata pacifier action by increased circulation \&vasodilatation leads to Improves motor function, bulk and strength. Relieves pain, stiffness $(33,34)$

\section{Discussion}

According to Ayurveda, body and mind have symbiotic association therefore, diseases of body and mind affect vice versa to each other (35). Relating to mental health and behavioral problems, ancient seers have described various mental diseases such as Apasmara ( epilepsy), Atatvabhinivesh ( schizophrenia) and Unmad( $\sim$ mania/psychosis) (36-37). Charak, Sushrut classifies 16 groups of psychics built and Kashyapa added two more (38-39). Classification of these psychic patterns is based on the developmental complex of ego and superego. Both ego and superego are formed by difference in the extent of combination of three attributes viz Satva, Raja, Tama. Satva is a responsible for mental health, while Raja and Tama are the causative factors of psychological problems. Sadavritta and $S C$ are responsible for strengthening Satva and controlling Raja and Tama. It is understood that Satva predominant activity i.e. work done with detachment from result can not affect individuals mind hence, focus should be on accomplishment of deeds without fear of outcome. Childhood age is the best time for development and lifelong dominance of these three attributes. Therefore, increasing Satva in childhood age can prove a strong preventive measure from BD and PD.

Growing children are continuously subjected to social, cultural and parental discipline. Hence, to increase their Satva attribute there should be gradual withdrawal of bad habits with adopting good habits suitable for making acceptable behaviour, building patience, mental calmness and strength to overcome psychological or environmental triggers. As the root causes of BD \& PD are related with mind hence focus should be given to correct mental health first by balancing Satva, Raja and Tama by $S C$. The management in such situation consists of educating the parents to make them understand the developing psyche of the child (8), as intellectual blasphemy (Pragyaparadha) is leading cause amongst mental and physical derangements (40).

\section{Role of Counselling:}

It sorts out the problem with proper compliance to grievances. A good counselling helps in preventing psychosomatic or psychiatric illnesses. Counselling have other advantages such as, it boosts the self-respect and confidence of client or parents, it corrects the method of parenting, it is the basic intervention to rule out the causes of psychological illness and planning of therapy accordingly. (41)

\section{Role of Play Therapy}

It is an age-old therapy, described in Ayurveda also. Toys play a significant role in boosting mental health, growth and development of child. (42) It can be made more pleasurable, effective, inexpensive and easy to execute to release their hidden frustration, forgetting burdens or disappointments. Play therapy addresses several problems like anxiety, anger, depression, distractibility and non-compliance. As play therapy involves both physical and mental discipline hence, it can be considered as a novel way in prevention of $\mathrm{BD}$ and PD (43). Violent toys help the release of anger, irritability, hostility and other emotions that can be freed through destruction. Real-life toys target withdrawn children that may be timid, shy, or introverted. Creative-expression toys give a wide range of expressive emotions that promote creativity (44).

\section{Application of Cognitive Behavior therapy (CBT):}

The CBT model is based on a combination of the basic principles from behavioral and cognitive psychology. CBT is "problem-focused" and "actionoriented", meaning it is used to treat specific problems related to a diagnosed mental disorder and the therapist's role is to assist effective strategies to address the identified goals and decrease symptoms of the disorder (45). CBT is based on the belief that thought distortions and maladaptive behaviours play a role in the development and maintenance of psychological disorders and that symptoms and associated distress can be reduced by teaching new information-processing skills and coping mechanisms (46). As CBT is based on behaviours, and emotional regulation hence, it is a developed part of $S C$.

Mode of action of Sadvritta, $A R$ and $S C$ are through avoidance of misbehaviour as well as controlling indulgence of sense organs and mind with improper subjects (Asatmendriyarth sanyog). Inappropriate knowledge of object leads to rude or offensive speech and physical activities. Improper intellect and perception both are objects of Prajna. (conscious) Good Intellect, Dhee (Adaptation of new things), Dhruti (Controlling factor of mind) and Smruti(recalling power)are within the purview of mind 
which regulates mood, concentration, limits Raja-tama and augment Satva dominance by inhibiting Pragyaparadh. Thus, SC works on attention, cognitive and emotional domain by working on selfcare, compassion, ability to distract from negative thoughts, relaxation of body and mind in turn pacify anger, anxiety and irritability. $S C$ an Ayurveda Psychotherapy facilitate mental wellbeing and strength $(9,47)$ Sadvritta and $A R$ help the child to develop mentally strong as well as protect from psychosomatic, behavioral and psychiatric complaints. Acharyas have elaborated the counselling ethics separately in Sadvritta description (48).

Acharyas have described the role of Asatmyendriyartha Samyoga, Pragyaparadha and Parinama in inducing the pathological conditions in body and mind. They are accountable for vitiating for all Sharirik Dosha and Manas Doshas - Pragyaparadha means unbalanced act in less, excess or unusual way (49). For this inducer, control over mind is necessary. It consists of preventing the mind from the desire of unwholesome objects with right understanding and spirituality of all sense organs to avert PD, BD and psychic diseases (50). Mental health is very important for child's social and cognitive development. $A R$ i.e. code of conduct as described above is the need of the hour. Also, Acharyas have explained DO's and Don'ts in terms of $A R$ which is mentioned in Table no 4 thereby control the misbehaviour at earliest and direct guidelines to parents. $(26,48,49)$

\section{Table no.4: Do's and Don'ts for parents:}

\begin{tabular}{|l|l|l|}
\hline $\begin{array}{l}\text { Sr.N } \\
\text { o. }\end{array}$ & Do's & Don't \\
\hline 1 & $\begin{array}{l}\text { Remove the bad habits } \\
\text { by soft words time to } \\
\text { time }\end{array}$ & $\begin{array}{l}\text { Punishment in front of } \\
\text { others or be scolded } \\
\text { them for their mistakes }\end{array}$ \\
\hline 2 & $\begin{array}{l}\text { Try to excuse them for } \\
\text { their mistakes. First } \\
\text { listen to them and then } \\
\text { guide }\end{array}$ & $\begin{array}{l}\text { Rude or over excited, so } \\
\text { strict or over } \\
\text { disciplined. }\end{array}$ \\
\hline 3 & $\begin{array}{l}\text { Give affirmative } \\
\text { instructions than } \\
\text { negative one. }\end{array}$ & $\begin{array}{l}\text { Stick so much with your } \\
\text { principles. }\end{array}$ \\
\hline 4 & $\begin{array}{l}\text { Be relax and flexible } \\
\text { according to situation }\end{array}$ & $\begin{array}{l}\text { Anticipate many task/ } \\
\text { ambitions at a time }\end{array}$ \\
\hline 5 & $\begin{array}{l}\text { Motivate as per the } \\
\text { child's capability }\end{array}$ & $\begin{array}{l}\text { Compare with one child } \\
\text { to another }\end{array}$ \\
\hline 6 & $\begin{array}{l}\text { Avoid pampering, } \\
\text { explain the reason of } \\
\text { deny. }\end{array}$ & $\begin{array}{l}\text { Fulfill their all desires } \\
\text { otherwise they will } \\
\text { become impulsive. }\end{array}$ \\
\hline
\end{tabular}

Role of Panchkarma and Ayurvedic formulations:

Number of herbal \& herbo-mineral formulations can be advised to curb the problems of children cited in Table no. 5 with their mode of action. Along with or without panchkarma, these medicines can work in this regard. Ashwagandha, Yashtimadhu, Guduchi, Mandukparni, Bramhi, Shankhapushpi, Jatamansi, Jyotishmati, Vacha.
Table no.5: Ayurvedic herbs and their role in

psychological problems $(15,21,31,51,52)$.

\section{SNo. Botanical name \& Sanskrit name \\ Mode of action}

Neuroprotective, brain growth booster, Proven

\begin{tabular}{l|l} 
& Mandukparni- \\
Centellaasitica \\
Linn.
\end{tabular}

2 Bramhi-Bacopa monnieri Linn. Madhuyashti/

3 Glycyrrhiza glabra Linn

\begin{tabular}{|l|l|l|} 
Jatamansi- & $\begin{array}{l}\text { Nardostachys } \\
\text { jatamansi (D. Don) } \\
\text { DC. }\end{array}$ & $\begin{array}{l}\text { Role in brain and } \\
\text { memory disorders in } \\
\text { the elderly. }\end{array}$ \\
\hline 5 & $\begin{array}{l}\text { Shankhpushpi- } \\
\text { Convolvulus } \\
\text { pluricaulis } \text { Chois. }\end{array}$ & $\begin{array}{l}\text { Nervine tonic, } \\
\text { stimulant to nervous } \\
\text { system }\end{array}$ \\
\hline
\end{tabular}

6 Tinosporacordifolia Wild Miers.

\begin{tabular}{|l|l|}
\hline 7 & $\begin{array}{l}\text { Ashwagandha- } \\
\text { Withania somnifera } \\
\text { Linn. }\end{array}$ \\
\hline 8 & $\begin{array}{l}\text { Jyotishmati- } \\
\text { Celastrus } \\
\text { paniculatus Willd }\end{array}$ \\
\hline 9 & $\begin{array}{l}\text { Vacha-Acorus } \\
\text { calamus Linn. }\end{array}$ \\
\hline
\end{tabular}

Anti-oxidant, nervine cum general tonic

Anti-stress, antianxiety, antioxidant

Inhibition of Acetyl choline

Sharpens IQ, memory, helps in neurodevelopment
3 Yashtimadhu-

Medhya medicines may regulate the neuropsychological process, stimulate alpha waves, sensory-motor centers of brain, and correct the mental disturbances.

Kalyanaka Ghrit, Panchagavya Ghrit, Smrutisagar Rasa Vati, Medhya Rasayana, etc (51).

Ghrit kalpas play an important role in prevention and management of psychic, psychosomatic and CNS issues (53).

Number of research studies have proven that Panchakarma pre procedures, major procedures with Ayurvedic medication have good impact on conduct disorders by maintaining Dhruti and preventing ethics negligence. Doshik imbalance can be taken care with the help of panchkarma to detoxify toxins, facilitate adequate nutrition to Dhatus and balance equilibrium in brain. Stress plays a vital role for inequilibrium of Dhee, Dhruti and Smruti. Panchkarma, Pranayam (breathing techniques), Yogasanas (postures), BandhaMudras (postural relaxation and meditation ways) and medhya medicines relieve stress and maintain the proper function of neurotransmitters and in turn central nervous system.

Shirodhara results in vasodilatation, transcutaneous penetration of oil, tactile and thermo- 
receptors stimulation to nerve endings. It stimulates to Marmas (vital areas of the body) increases circulation and also enhances action of neurotransmitters like Serotonin, Nor-epinephrine and metabolism of Dopamine and catacholamines. Pressure of Dhara has an effect on impulse conduction, removes Aam/toxins, relieves Strotorodha (channels obstruction) and nourishes cells to feel relax and gives natural tranquilizing effect $(33,34)$. Shirodhara with Medhya dravya provides strength to Prana \& Indriyas which are mainly Vata vitiated in case of psychological disordersShirodhara promotes a decrease of noradrenaline and exhibits a sympatholytic effect and immunopotentiation For enhancement in concentration, awareness and selfesteem levels, multi therapy approach is needed with good parenting which would provide a sigh of relief toward search of ideal treatment for behavioral problems in children $(21,54)$.

Limitation of this review is that there is no RCTs or not many clinical studies could be added as

evidence to establish the role of Ayurveda principles except panchkarma procedures, yoga and few herbs. Although, principles (AR, SV, SC) are difficult to assess by scales to measure their efficacy therefore, need to focus on this area to conduct research.

\section{Conclusion}

Improvement of child behaviour is not completely depending on classroom educational teaching but mostly relies on good conduct, practical wisdom which is safe, can use long-term and of nonpharmacological approach, thereby apt to behave properly and tackle day to day problems with ease. Ayurveda can act as an excellent adjuvant in advanced stage or alone capable to deal with PD and BD with the help of Satvavajay, Acharrasayan, Sadvritta, Yog and nootropic medicines with Panchkarma and its preprocedures. It is imperative to direct them through elders to prevent behavioral and conduct problems with adoption of Ayurveda. Present study may prove as torchbearer for focusing the importance of Ayurveda in defeating the behavioral problems in children.

\section{References:}

1. World health report on mental disorders, available at http://www.who.int/whr/2001/mediacentre/ press_release/en/. 2001last accessed on 22nd Jun 2019, 10 am.

2. Kathleen RM; Erin FM; Ronald CK. Epidemiology of mental health disorders \& adolescents, Dialogues Clin Neurosci. 2009;11(1):7-20.

3. Sushma BV, Srinivasan V, Khyrunnisa B. Prevalence of Behavioral Problems among School Children and their Demographic Correlates. Guru J Behvioral and Soc Sci.2013;1(4): 203-212.

4. Elizabeth AS, Karen LB, Robert JMc. Parenting practices and child disruptive behavior problems in early elementary school. J Clin Child Psychol.2000;29(1):17-29.

5. Jason $\mathrm{CH}$. Association between different parenting styles \& Child behavior.2013; available at http:// digitalcommons.pcom.edu/cgi/viewcontent.cgi? article $=1261 \&$ cont ext $=$ psychology_dissertations, last accessed on 22nd Jun 2019, 11 am.

6. Parthasarathy A, Menon PSN, Mahadeviah, M. Mehta. Indian Academy of Pediatrics, Childhood disabilities, Indian Psychiatry, Behavior therapy, Vol.2, Reprint edition, Jaypee publisher,2005; pp.1049, 1218-27

7. Charaka Samhita-Agnivesh-Vidyotini Hindi commentary, KashinathSastri; G. Chaturvedi, 19th edition, Part 1, Sutrasthan, 7/54, Chaukhambha Bharati Academy, Varanasi, 1993, p.126

8. Renu Rathi, Bharat Rathi, Dhiraj Sing Rajput. Behavioural Problems in Children - Methods to Prevent and Manage through Good Parenting and Ayurveda. J. Res. Tradit. Med 2017; 3(4): 117-122

9. Charaka Samhita-Agnivesh-Vidyotini Hindi commentary, KashinathSastri; G. Chaturvedi, 19th edition, Part 1, Chikitsasthan, Rasayan adhyay (1/4:33), p.58, ChaukhambhaBharati Academy, Varanasi, 1993

10. Charaka Samhita-Agnivesh-Vidyotini Hindi commentary, KashinathSastri; G. Chaturvedi, 19 edition, Part $1, \quad$ Sutrasthan, Indriyopakramaniyodhyay (8:18), p.123, Chaukhambha Bharati Academy, Varanasi, 1993

11. Charaka Samhita Agnivesh, Hindi commentary H.S.Kushvaha, 1st edition, Part 1, Sharirsthan, KhuddikamGarbhavkrantishariram( 3:16),p-795, ChaukhambhaOrientalia, Varanasi, 2005;

12. Khatana Rakesh, Rathi Renu, Khatana A. Role of Ayurveda in Down's syndrome- A case study. IJGHC-International journal of Green and Herbal Chemistry.2020;9(2):203-213

13. Rathi R. A Clinical study on GokshursiddhaYavagu and Dhatryavleha in fetus in cases of Toxemia of pregnancy, JNIMA; Mar 2013

14. Rathi R, Rathi B, Sharma S, Rajput DS. Management of childhood Protein Energy Malnutrition through Ayurvedic interventions. Joinsysmed2017, 5(3):196-202

15. Rathi R, Rathi B. Ayurveda perspectives towards Prevention and Management of Nicotine and Alcohol Dependence. J Indian Sys Medicine. 2020;8(1):14-28

16. Sushrut Samhita, Sushruta, Laxmikant Dwivedi, Edition 2nd, Sharirsthan, Garbhavkranti Shariram, (3:17), ChaukhambhaSanskritseries, Varanasi, 2002, p. 159

17. Mudzielwana NP, Makhwathana RM, \& Mudau TJ. Managing A. Mul ovhedzi, Children's Depression Behavior to Promote Mental Health Wellbeing in the Classroom. Journal of Psychology. 2016;7(2):86-92.

18. Banyard VL, Williams LM, Siegel JA. The impact of complex trauma and depression on parenting: an exploration of mediating risk and protective factors. Child Maltreat. 2003; 8(4):334-49.

19. Rathi Renu, Rathi B, Khatana R, Sankh S. A case study on management of Retts syndrome by Wholistic approach. IJAM,2020;11(2):351-357

20. Mills PJ, Patel S. Advancing Research on Traditional Whole system Medicine Approaches. 
Journal of Evidence based complementary \& Alternative Medicine (JEBCAM)2017; 22:52753022. Jyoti ST. Dimensions of Satvavajaya Chikitsa(Ayurvedic psychotherapy) \& their clinical applications. J Annals of Ayu Med. 2012; 1(1):31-38.248.

21. Marjorie Smith. Good Parenting: Making a difference. J. Early Human Development. (Early Hum Dev.)2010; 86(11):689-93. doi: 10.1016.

22. Gupta MC, Dhaked R. A critical review on Achara Rasayana. IJAR. 2016;2(3):633-5.

23. Baumrind D. Effects of Authoritative parental control in child behavior \& development. Child Development. 1966;37(4), 887-907.

24. Shilpa Sarpotdar. Palakansathi(Guidelines for development of good intelligence of children for Parents), Deep prakashan, Mumbai, 1st Edition, Feb. 1999; 22-48

25. Khedekar S, Rathi R, Rathi B. Rationale behind Ayurveda Codes of Conduct (Aachar Rasayana) in COVID-19 like new disorders - A critical review. Int $J$. of Research in Pharmaceutical ScienceIJRPS.2020;11(3):1-6

26. Sharma P.,Rathi R, Sharma N., Rathi B, Zadpe A \& JyotiRani. A case study on prevention and management of Attention Deficit Hyperactive Disorder. Europian jr. of Biomedical and Pharmaceutical Sciences.2020;7(7):421-426

27. Negi K, Singh Y, Kushwaha K., Rastogi C., Rathi A., Srivastava J., Asthana O., Gupta R. Clinical evaluation of memory enhancing properties of memory plus in children with attention deficit hyperactivity disorder. Indian J. Psychiatry.2000;42: (2)

28. Christine A. Conelea; Benjamin T; P. Tucker; Douglas W. Wods. A Handbook of Clinical Psychology Competencies- A comprehensive clinical assessment of Tics and Habit disorders in children. Springer publication. ISBN 0387097589,2007;1403-1428.

29. Singh R. Psychosomatic disorders and their Management in Ayurved, Ancient Science of Life. 1981; 1(1): 4148

30. Sharma A, Gotecha VK, Ozha N. A solution through Ayurved evidences In Dyslexia management: A Review.2012;33(4): 486-490

31. Rathi R, Rathi B. Chapter in Book on Best Practices in Panchkarma Chapter on Comparative efficacy of therapeutic Pnachkarma procedures in children with Cerebral Palsy, IS B N : 978-93-5268-176-1Publisher-Registrar, DMIMS, 2017

32. Singh RH. Pancakrama Therapy, Edition Reprint, Chowkhamba Sanskrit Series Office Varanasi. 2007;184-199

33. Tiwari R.P., Dwivedi S.R. et al. Psychological disorders in children and their therapy as per Ayurveda, Int archieves of Integrated Medicine.2014;1(4):96-99.

34. Agnivesh, KashinathSastri; G. Chaturvedi Vidyotini Hindi commentary CharakSamhita $19^{\text {th }}$ edition Part I1, Chikitsasthan Unmad Chikitsaadhyaya 9:5,
Chaukhambha Bharati Academy, Varanasi, 1993; p-305

35. Agnivesh, KashinathSastri; G. Chaturvedi Vidyotini Hindi commentary, CharakSamhita. 19th edition Part 1, Sharir sthan Maheti Garbhavkranti adhyaya:36, p- 772 Chaukhambha Bharati Academy, Varanasi, 1993;

36. Sushrut, Dalhan. P.V. Sharma. SushrutSamhita, Vol.II Sharir sthan garbhavyakarnaadhyaya 4/84-89, Edition Reprint, ChaukhambhaVisvabharati, Varanasi, 2005; p-119.

37. Kashyap. P.V. Tiwari. Kashyapsamhita. $1^{\text {st }}$ edition, Sutrasthan, lakshnaadhyaya, 28:8-9, Chaukhambha Visvabharati, Varanasi, 1996; p-81.

38. Sushrut, Dalhan.V. Sharma Sushrut Samhita, Reprint edition, Sharirsthan, garbha vyakarna adhyaya4:64, ChaukhambhaVisvabharati, Varanasi; 2005. p-162.;

39. Sushrut. Sushrut Samhita. Sharirsthan, Sarvabhutachintaadhyaya1:20-21, Chaukhambha Visvabharati, Varanasi, Reprint edition, P.V. Sharma;2005; p-124-5

40. Naderi F, A. Heidarie, L. Bouron and P. Asgari. The Efficacy of Play Therapy on ADHD, Anxiety and Social Maturity in 8 to 12 Years Aged Clientele Children of Ahwaz Metropolitan

41. Kashyap. P.V. Tiwari. Kashyapsamhita. $1^{\text {st }}$ edition, Khilsthan 8/12, Chaukhambha Visvabharati, Varanasi, 1996, p-281

42. Tara M. Hall, Charles E. Schaefer. Fairleigh Dickinson University, Heidi Gerard Kaduson-Play Therapy Training Institute,Fifteen effective play therapy techniques, Professional psychology: Research \& practice, 2002;33(6):515-522

43. Behavioral-therapy-for-children-with-emotionaldisorders, available at http:// www.kidsmentalhealth.org/ /Accessed on september 28,2019 .) Last accessed on 22nd Jun 2020, $10 \mathrm{pm}$.

44. Beck JS. Cognitive behavior therapy: Basics and beyond (2nd ed.), New York, NY: The Guilford Press, 2011; 19-20

45. Charaka Samhita. Agnivesh., Kashinath Sastri; G. Chaturvedi Vidyotini Hindi commentary, 2ndvol., Sutrasthan Triyeshaniya Adhyaya 11/54, Chaukhambha Orientalia, Varanasi.2 $2^{\text {nd }}$ edition 2008, p-184

46. Agnivesh, Dridhabala, Kashinath Sastri; G. Chaturvedi. Charaka Samhita Vidyotini Hindi commentary $2^{\text {nd }}$ edition, $2^{\text {nd }}$ vol. Sutrasthan, Indriyaupkarniyaadhyaya 8:16-33, Chaukhambha Orientalia, Varanasi, 2008; $\mathrm{p}-125-130$

47. Agnivesh, Dridhabala, Kashinath Sastri; G. Chaturvedi. Charaka Samhita, Vidyotini Hindi commentary, 2nd edition, Sharirasthan Kathidhapurshiya adyaya $1: 102,127$ \& Sutrasthan Triyashniyaadhyaya 11:54. Chaukhambha Orientalia, Varanasi.2008, p-994

48. Agnivesh, Dridhabala, Kashinath Sastri; G. Chaturvedi. Charaka Samhita, Vidyotini Hindi commentary2nd vol. Sutrasthan Navegadharniya adhyaya 7:54-65, Chaukhambha Orientalia, Varanasi. $2^{\text {nd }}$ edition, 2008; p-119 
49. Suman Ray, Asim Ray. Medhya Rasayan in brain function and Disease. Medicinal Chemistry. 2015; 5(12):505-511

50. Singh RH. Psychosomatic disorders and their Management in Ayurved. Ancient Science of Life. 1981; 1(1): 4148

51. Rathi B. Rajput, D. Wanjari A. Rathi R. Physico Chemical Analysis of Purana Ghrita (Old Clarified
Butter) with 294 special reference to. Fatty Acid Profile. J Ind Sys Med, 2018; 6(1):4-9.

52. Singh AK, Singh M, Gupta AK, Singh PK. Life Style disorders "A curse of Modern Society" and it's management with Ayurveda. Unique Journal of Ayurvedic and Herbal Medicines. 2014, 02 (01): $1-5$. 